\title{
GMR
}

\section{Cytotoxic and genotoxic potential of geraniol in peripheral blood mononuclear cells and human hepatoma cell line (HepG2)}

\author{
T.B. Queiroz ${ }^{1}$, G.F. Santos ${ }^{2}$, S.C. Ventura ${ }^{2}$, C.A. Hiruma-Lima ${ }^{1}$, \\ I.O.M. Gaivão ${ }^{3}$ and E.L. Maistro ${ }^{1,2}$ \\ ${ }^{1}$ Pós-Graduação em Biologia Geral e Aplicada, Instituto de Biociências, \\ Universidade Estadual Paulista, Botucatu, SP, Brasil \\ ${ }^{2}$ Departamento de Fonoaudiologia, Faculdade de Filosofia e Ciências, \\ Universidade Estadual Paulista, Marília, SP, Brasil \\ ${ }^{3}$ CECAV and Department of Genetics and Biotechnology, \\ Trás-os-Montes and Alto Douro University, Vila Real, Portugal \\ Corresponding author: E.L. Maistro \\ E-mail: edson.maistro@marilia.unesp.br
}

Genet. Mol. Res. 16 (3): gmr16039777

Received July 17, 2017

Accepted August 28, 2017

Published September 27, 2017

DOI http://dx.doi.org/10.4238/gmr16039777

Copyright $\left({ }^{\circ} 2017\right.$ The Authors. This is an open-access article distributed under the terms of the Creative Commons Attribution ShareAlike (CC BY-SA) 4.0 License.

\begin{abstract}
Geraniol is an acyclic monoterpene alcohol present in the essential oil of many aromatic plants and is one of the most frequently used molecules by the flavor and fragrance industries. The literature also reports its therapeutic potential, highlighting itself especially as a likely molecule for the development of drugs against cancer. In view of these considerations, this study was designed to evaluate the cytotoxic and genotoxic potential of geraniol, in an in vitro protocol, using two types of human cells: one without the ability to metabolize (peripheral blood mononuclear cells - PBMC), and the other with this capability (human hepatoma cell line - HepG2) through the comet assay and the micronucleus test. Four concentrations $(10,25,50$, and $100 \mu \mathrm{g} /$ $\mathrm{mL}$ ) were selected for the genotoxic assessment for PBMC and three
\end{abstract}


$(1.25,2.5$, and $5 \mu \mathrm{g} / \mathrm{mL})$ for HepG2 cells based on cytotoxicity tests (MTT assay). Results showed that geraniol did not present genotoxic or clastogenic/aneugenic effects on both cell types under the conditions studied. However, caution is advised in the use of this substance by humans, since a significant reduction in viability of HepG2 and a marked decrease in cell viability on normal PBMC were verified.

Key words: Monoterpene; Geraniol; Comet assay; Micronucleus test; MTT assay

\section{INTRODUCTION}

Essential oils (EO) are synthesized by aromatic plants as secondary metabolites. EO are extracted by steam or hydrodistillation or by compression of citrus fruit pericarp (Bakkali et al., 2008). Numerous organic compounds (approximately from 20 to 60), as hydrocarbons, alcohols, ketones, aldehydes, coumarins, lactones, among others, are found in the EO at different concentrations. Few EO present only one single component in high percentage. Usually, there is one major compound, followed by others of the minor level, as well as some others called "trace" components, present in small quantities, but often essential to the odor and aroma composition (Bakkali et al., 2008). For example, in the EO of Lippia alba leaves there were identified a total of 42 constituents, but major components were linalool (50.079.2\%) and 1,8-cineol (7.3-14.1\%) (Barros et al., 2009). The major constituent of an EO is normally determined by its biological properties (Bakkali et al., 2008).

The most common compounds in the EO are monoterpenes (Bakkali et al., 2008), a non-nutritive dietary substance mainly responsible for the distinctive fragrance of many plants. Due to its particularities, they have been widely used as flavoring agent in food, beverages, and cosmetic industries (Bakkali et al., 2008). Therapeutic activity has been related to the EO of various plant species due to the presence of monoterpenes in their composition (Bakkali et al., 2008; Bhalla et al., 2013; Sobral et al., 2014).

Present in more than 160 EO (Burdock, 2010), geraniol (trans-3,7-dimethyl-2,6-octadien$1-\mathrm{ol}$ ) is an acyclic monoterpene alcohol, mainly isolated from the palmarosa oil (Cymbopogon martinii) (53.5-65\%), but also commonly found in other EO, such as Monarda fistulosa, rose, and citronella oils. Geraniol is an important component of the EO of citrus fruit, such as lemon, lime, and orange; seeds, as nutmeg; many vegetable, as ginger; and medicinal plants, particularly plants of the Cymbopogon genus (Lapczynski et al., 2008; Chen and Viljoen, 2010; Vieira et al., 2011; Madankumar et al., 2013; Sharma et al., 2016). Several institutions, including the Food and Drug Administration, recognized geraniol as a reliable flavoring agent, and its use is allowed by the Council of Europe in foodstuffs (Lapczynski et al., 2008).

Geraniol exerts a broad spectrum of pharmacological activities, such as anti-oxidant, anti-microbial, anti-inflammatory, neuroprotective, and anti-ulcer effects (Solórzano-Santos and Miranda-Novales, 2012; Rekha et al., 2013; Carvalho et al., 2014), as well as repellent and insecticide actions (Chen and Viljoen, 2010). Geraniol, as occur with some other monoterpenes, has also been shown to present in vitro and in vivo antitumor effects against murine leukemia, hepatoma, melanoma, colon cancer cells, prostate cancer, oral carcinogenesis, acting even in preneoplastic lesions (Burke et al., 1997; Carnesecchi et al., 2001; Usta et al., 2009; Chen and Viljoen; 2010; Vieira et al., 2011; Madankumar et al., 2013; Cho et al., 2016; Lee et al., 2016).

Genetics and Molecular Research 16 (3): gmr16039777 
Furthermore, geraniol proved to sensitize the human colonic cancer cells (Caco-2 cell line) to the treatment with 5-fluorouracil, an anticancer drug used for colorectal therapy (Carnesecchi et al., 2002).

Some reactive compounds are present in a subtoxic concentration in the organism - i.e., unable to trigger cell death -; in this case, it can interact with DNA molecule directly, resulting in several damage types, including promutagenic lesions, whether they are caused by themselves or system DNA repair failures, could lead to cell malignant transformation (Eisenbrand et al., 2002). So, it is essential to certify the biosafety in the use of geraniol by humans, assessing their direct and indirect effects after metabolization in the cells.

The evaluation of the genotoxic potential of chemical and pharmaceutical compounds is of fundamental importance, considering the relationship between mutation and human diseases including cancer (Tennant, 2014). International regulatory agencies, including the Guidelines of the Scientific Committee on Food, validated and recommended some genetic tests for the genotoxic assessment, and comet and micronucleus assays are among some of these (Llana-Ruiz-Cabello et al., 2015). The alkaline comet assay is used to identify substances that cause DNA single- and double-strand breaks, as a result of its direct or other interactions with DNA molecule (OECD TG 489, 2014). Micronucleus test is a method that permits the detection of chromosome damaging agents that can act as clastogens (chromosome breakage agents) and/or aneugens (spindle dysfunction agents) (Maistro, 2014; OECD TG 487, 2014).

Our literature review evidenced that the cytotoxic, genotoxic, and mutagenic assessment of geraniol using different models and protocols showed contrasting and some inconclusive results (Ishidate et al., 1984; Doppalapudi et al., 2007; Sinha et al., 2014). Thus, considering that some essential oils and/or its constituents can present toxic effects, as well as misuse, can cause serious poisoning (Woolf, 1999), the present study was designed to assess the cytotoxic (by the MTT assay) and genotoxic potential (by the comet assay and micronucleus test) of geraniol, in an in vitro protocol, using two human cell types: i) human peripheral blood mononuclear cells (PBMC), and ii) human hepatoma cell line (HepG2), respectively, to evaluate its direct effects and after liver enzymes metabolization.

\section{MATERIAL AND METHODS}

\section{Test substance and chemical compounds}

Geraniol (Sigma-Aldrich ${ }^{\circledR}$, CAS number 106-24-1, 98\% purity) was diluted in $8 \%$ Tween 80 (Dinâmica ${ }^{\mathbb{R}}$ ) solution to be tested with human cells. Methyl methanesulfonate (MMS) (Sigma-Aldrich ${ }^{\circledR}$, CAS number 66-27-3) and Benzo(a)pyrene (BaP) (SigmaAldrich $^{\circledR}$, Lot: LC04528V) were used as the positive control, due to its potential for DNA damage, recognizable in the comet and micronucleus assays. The other main chemicals were obtained from the following suppliers: 3-(4,5-dimethylthiazol-2-yl)-2,5-diphenyltetrazolium bromide (MTT) (Invitrogen ${ }^{\mathrm{TM}}$, Lot: 1178042), antibiotic-antimycotic (Gibco ${ }^{\circledR}$, Ref. 15240062), Cytochalasin-B (Sigma-Aldrich ${ }^{\circledR}$ ), dimethyl sulfoxide (DMSO) (Sigma-Aldrich ${ }^{\circledR}$ ), ethidium bromide (Sigma-Aldrich ${ }^{\circledR}$ ), ethylenediaminetetraacetic acid (EDTA) (Synth), fetal bovine serum (FBS) $\left(\right.$ Gibco $\left.^{\circledR}\right)$, Giemsa (Synth), Histopaque ${ }^{\circledR} 1077\left(\right.$ Sigma $\left.^{\circledR}\right)$, low-melting point (LMP) agarose $\left(\right.$ Invitrogen $\left.^{\mathrm{TM}}\right)$, Eagle's minimum essential medium (MEM) $\left(\mathrm{Gibco}^{\circledR}\right)$, Phytohemagglutinin-A (Sigma-Aldrich ${ }^{\circledR}$ ), RPMI (Roswell Park Memorial Institute) 1640 medium $\left(\right.$ Gibco $\left.^{\circledR}\right)$, sodium pyruvate $\left(\right.$ Gibco $\left.^{\circledR}\right)$, Triton ${ }^{\mathrm{TM}}$ X-100 $\left(\right.$ Sigma-Aldrich $\left.^{\circledR}\right)$, Trypsin $\left(\right.$ Sigma $^{\circledR}$, Lot: 039K7013), and UltraPure ${ }^{\mathrm{TM}}$ agarose (Invitrogen ${ }^{\mathrm{TM}}$ ).

Genetics and Molecular Research 16 (3): gmr16039777 


\section{Cell types}

Two cell types were used in this research: PBMC (non-metabolizing cells) collected from 2 healthy ( 1 male and 1 female), non-smoking volunteers, aged from 18 to 35 years old, and HepG2, having phase 1 and phase 2 enzymes (metabolizing cells) (Hewitt and Hewitt, 2004). Donors of peripheral blood provided a written informed consent at the time of donation, for the use of their blood sample in this study. The Human Ethics Committee of the São Paulo State University "Júlio de Mesquita Filho" (UNESP), of Marília town, Brazil, approved the present study on August 6, 2014 (protocol 1009/2014). HepG2 cells were obtained from the Rio de Janeiro Cell Bank, located in the Federal University of Rio de Janeiro, Brazil.

The PBMC was cultivated in RPMI 1640 medium, supplemented with $15-20 \%$ FBS, and $1 \%$ antibiotic-antimycotic; and the HepG2 was cultivated in MEM with $2.2 \mathrm{mg} / \mathrm{mL}$ sodium bicarbonate $\left(\mathrm{NaHCO}_{3}\right)$, and $1 \%$ sodium pyruvate, supplemented with $10 \%$ FBS and $1 \%$ antibiotic-antimycotic, in an incubator at $37^{\circ} \mathrm{C}, 5 \% \mathrm{CO}_{2}$, and $95 \%$ relative humidity for both.

\section{Cytotoxicity analysis}

The cytotoxicity test was performed in triplicate for controls and treatments on both cell types using MTT assay described by Mosmann (1983), with some modifications. This test is based on the reduction of the MTT tetrazolium salt ring by mitochondrial dehydrogenase enzymes of viable cells, generating a purple product (named formazan crystals), which accumulates inside the cells and can be measured by a spectrophotometer. The optical densities obtained are directly proportional to the viable cell number (Mosmann, 1983).

PBMC, isolated with Histopaque ${ }^{\circledR}-1077$, and HepG2 cells were seeded on 96-well plates at concentrations of $2 \times 10^{4}$ and $1 \times 10^{4}$ cells/well, respectively, containing $250 \mu \mathrm{L}$ of the respective culture medium, for $24 \mathrm{~h}$ at $37^{\circ} \mathrm{C}$. After this time, the medium was discarded, and the cells were exposed to geraniol for another $24 \mathrm{~h}\left(37^{\circ} \mathrm{C}\right)$ in the following concentrations: $2.5,5,10,25,50,100,250,500$, and $1000 \mu \mathrm{g} / \mathrm{mL}$, finishing with the new culture medium (with FBS) in a final volume of $250 \mu \mathrm{L} /$ well. For reading samples, blank wells only composed of medium without FBS was prepared in triplicate. Tween 80 solution $(8 \%)$ was the negative control, and the positive control was Triton X-100 (Sigma-Aldrich) diluted in the culture medium (without FBS) related to each cell type, at a concentration of $1 \%$.

After this period, the medium of the wells was removed, and $150 \mu \mathrm{L} /$ well MTT $(0.5$ $\mathrm{mg} / \mathrm{mL}$ ) was added, and the plates were incubated for $4 \mathrm{~h}$ at $37^{\circ} \mathrm{C}$. The MTT undergo an initial dilution in PBS $(5 \mathrm{mg} / \mathrm{mL})$, obtaining the stock solution, which was filtered and sterilized. To use in culture, the stock solution was diluted in serum free medium (RPMI-1640 or MEM for PBMC and HepG2 cells, respectively) in the proportion of 1:9 (v/v). At the end of the $4 \mathrm{~h}$, the MTT was removed, and $100 \mu \mathrm{L} /$ well DMSO was added to solubilization of the formazan crystals. The plates remained gently shaking for at least $15 \mathrm{~min}$ and were then read with a microplate spectrophotometer (Epoch-BioTek ${ }^{\circledR}$ ) at a wavelength of $550 \mathrm{~nm}$. The percentage of viable cells was obtained by division of the mean absorbance of each exposure by the mean absorbance of the negative control after having been subtracted the mean absorbance of the blank wells.

\section{Single-cell gel electrophoresis (comet assay)}

The experiments were performed in triplicate to each control and concentration of

Genetics and Molecular Research 16 (3): gmr16039777 
geraniol on both cell types, according to the method described by Singh et al. (1988) and Klaude et al. (1996), with some modifications. PBMC isolated with Histopaque ${ }^{\circledR}-1077$ and HepG2 cells were cultivated for $24 \mathrm{~h}\left(37^{\circ} \mathrm{C}\right)$ at a concentration of $1 \times 10^{5}$ cells/well on 24 -well plates. After this time, the cells were exposed for $4 \mathrm{~h}$ to geraniol concentrations selected by the MTT assay. MMS $(45 \mu \mathrm{M})$ was employed as a positive control (OECD 489, 2014), and $20 \mu \mathrm{L}$ $8 \%$ Tween 80 solution was used as a negative control.

At the end of the exposure time, the PBMC and the HepG2 (after pretreatment with trypsin $0.5 \%$ EDTA) cells were centrifuged at $1500 \mathrm{rpm}$ for 10 and $5 \mathrm{~min}$, respectively, and the supernatant was discarded, leaving approximately $100 \mu \mathrm{L}$ to resuspend pellets. This cell suspension volume of each tube/cell type was mixed with $100 \mu \mathrm{L} 0.5 \%$ LMP agarose $\left(37^{\circ} \mathrm{C}\right)$, and the same volume was deposited on a previously prepared thin layer $1.5 \%$ UltraPure $^{\mathrm{TM}}$ agarose slide, and then covered with cover glass. For agarose hardening, the slides were refrigerated at $4^{\circ} \mathrm{C}$ for $20 \mathrm{~min}$. Finished this time, the cover glasses were removed, and the slides deposited in a vat containing cold lysis solution $(2.5 \mathrm{M} \mathrm{NaCl}, 100 \mathrm{mM}$ EDTA, $10 \mathrm{mM}$ Tris, $1 \%$ Triton $\mathrm{X}-100$ and $10 \% \mathrm{DMSO}, \mathrm{pH} 10$ ), and kept at $4^{\circ} \mathrm{C}$ for at least $1 \mathrm{~h}$, protected from the light.

After the lysis, the slides were forwarded to electrophoresis box in ice bath, in the absence of light to prevent additional DNA damage, and remained in alkaline buffer $(0.5 \% 200$ mM EDTA solution, $3 \% 10 \mathrm{~N} \mathrm{NaOH}$ solution, deionized water at $4^{\circ} \mathrm{C}, \mathrm{pH}>13$ ), which detect single- and double-stranded breaks, for $20 \mathrm{~min}$ for DNA denaturation. Next, the electrophoresis was carried out at $25 \mathrm{~V}(1 \mathrm{~V} / \mathrm{cm}, 300 \mathrm{~mA})$ for $20 \mathrm{~min}$; then, neutralization was performed three times ( $0.4 \mathrm{M}$ Tris solution, $\mathrm{pH} 7.5)$ for $5 \mathrm{~min}$ each, to remove alkali and detergents that would interfere with staining. The slides were dried at room temperature and fixed in absolute ethanol for $10 \mathrm{~min}$. The dried slides were stored in the refrigerator until the moment of the analysis. In the absence of light, the slides were stained with $200 \mu \mathrm{g} / \mathrm{mL}$ ethidium bromide solution and analysis were performed with a fluorescence microscope (Olympus - excitation filter: 515-560 $\mathrm{nm}$; emission filter: $590 \mathrm{~nm}$ ) with 400X magnification, immediately.

The extent and distribution of DNA damage indicated by the single-cell gel electrophoresis assay were conducted by examining at least 100 randomly selected and nonoverlapping cells (100 cells per coded slide) per culture well, in a blind analysis. These cells were scored visually, according to tail size, into the following 4 classes: class 0 - no tail; class 1 - tail shorter than the diameter of the head (nucleus); class 2 - tail length 1 to 2 times greater than the diameter of the head; and class 3 - tail length more than twice the diameter of the head. Comets with no heads having almost the entire DNA in the tail or with a wide tail were scored separately from the evaluation because these probably represented dead cells (Hartmann and Speit, 1997). The total score for 100 comets, which ranged from 0 (no damage) to 300 (severe damage), was obtained from the sum of multiplying the number of cells in each class with the damage class. Apoptotic and necrotic cells were not considered.

\section{Cytokinesis block micronucleus (CBMN) assay}

The CBMN assay was developed according to the methodology described by Fenech (2000). The experiments were performed in duplicate in human peripheral blood lymphocytes from two donors, and in triplicate in HepG2 cells, for controls and each geraniol concentration.

To the human lymphocyte cultures, each $10-\mathrm{cm}^{2}$ flat face culture tubes $\left(\mathrm{TPP}^{\circledR}\right)$ were prepared with $5 \mathrm{~mL}$ supplemented RPMI 1640 medium, further $5 \mu \mathrm{g} / \mathrm{mL}$ Phytohemagglutinin-A

Genetics and Molecular Research 16 (3): gmr16039777 
to stimulate lymphocyte division, and $0.5 \mathrm{~mL}$ plasma followed by 6 to 8 drops erythrocyte concentrates. The tubes were incubated for $72 \mathrm{~h}$ at $37^{\circ} \mathrm{C}, 5 \% \mathrm{CO}_{2}$, and $95 \%$ air. The exposure to geraniol was made $44 \mathrm{~h}$ after incubation with the geraniol concentrations previously determined by the MTT assay. The positive control was MMS $(150 \mu \mathrm{M})(\mathrm{OECD}$ TG 487, $2014)$, and the negative control the $8 \%$ Tween 80 solution $(50 \mu \mathrm{L})$. Four hours after the addition of test compound, Cytochalasin-B $(6 \mu \mathrm{g} / \mathrm{mL})$ was added to each culture.

For HepG2 cells, $25-\mathrm{cm}^{2}$ culture flasks (TPP ${ }^{\circledR}$ ) were prepared with $5 \mathrm{~mL}$ supplemented MEM at a cell concentration of $2 \times 10^{5}$. The cells were cultured at $37^{\circ} \mathrm{C}, 5 \% \mathrm{CO}_{2}$ and $95 \%$ air, until a complete cell cycle $(24 \mathrm{~h})$. After the exposure to geraniol was made with the concentrations previously determined by the MTT test for $24 \mathrm{~h}, \mathrm{BaP}(2 \mu \mathrm{M})$ was employed as a positive control (OECD TG 487, 2014) and the negative control was the same mentioned above for the PBMC cells. Finished this time, the culture medium of all flasks was discarded, and the cells were washed with $5 \mathrm{~mL}$ PBS, which was removed. Cytochalasin B $(6 \mu \mathrm{g} / \mathrm{mL})$ was added to each flask together with culture medium, and the flasks were incubated for more $28 \mathrm{~h}$. Next, the cells were washed and transferred to centrifuge tubes after treatment with trypsin $0.5 \%$ EDTA.

The cultures of both cell types were centrifuged for $5 \mathrm{~min}$, and the pellets suspended in $0.075 \mathrm{M} \mathrm{KCl}$ hypotonic solution and $10 \mathrm{mg} / \mathrm{mL}$ sodium citrate solution, both at $4^{\circ} \mathrm{C}$, respectively, for lymphocytes and HepG2 cells. Again, the cells were centrifuged, and fixed in a cold solution 3:4 and 3:1 ratio methanol and acetic acid to lymphocytes and HepG2, respectively. This step was repeated twice and a 5:1 ratio fixative for lymphocytes was used. In the first fixation, $4 \%$ formaldehyde drops were added for the cytoplasm preservation. The slides were prepared by dripping and stained with $10 \%$ Giemsa for $10 \mathrm{~min}$.

The analysis was performed in the light microscope (Zeiss, Primo Star) with 400X magnification, with the count of 1000 binucleated cells for exposure/repetition and controls, noting the presence of micronucleus, nucleoplasmic bridges, and nuclear buds in the cells. An additional cytotoxicity measure was calculated using the nuclear division index (NDI), according to the formula: $[\mathrm{M} 1+2(\mathrm{M} 2)+3(\mathrm{M} 3)+4(\mathrm{M} 4) / \mathrm{N}]$, in which M1-M4 indicates the cell number containing 1-4 nucleus assessed in a total of 500 cells $(\mathrm{N})$ to each exposure/repetition and controls.

\section{Statistical analysis}

All data obtained by the comet assay and micronucleus test for both cell types were analyzed statistically, employing one-way analysis of variance (ANOVA) and Tukey multiple comparison tests, using the GraphPad Prism ${ }^{\circledR} 5$ software (version 5.02). Micronucleus data from PBMC were statistically analyzed with the $F$-test for ANOVA, and the significance of differences between the negative control and treated groups was determined with the Dunnett $t$-test. The results of the comparison between the controls and the geraniol concentrations were considered statistically significant with $95 \%$ confidence interval $(\mathrm{P}<0.05)$.

\section{RESULTS}

Through the quantitative colorimetric assay with the MTT tetrazolium salt, it was possible to evaluate the cytotoxic potential of geraniol for $24 \mathrm{~h}$ forward PBMC and HepG2, having been selected to cytotoxic assays the concentrations with cell viability results $\geq 80 \%$. In PBMC, concentrations less than or equal to $100 \mu \mathrm{g} / \mathrm{mL}$ presented over $90 \%$ of viable cells. However, a drastic reduction in cell viability from the concentration of $250 \mu \mathrm{g} / \mathrm{mL}$ onwards

Genetics and Molecular Research 16 (3): gmr16039777 
was shown, whose viable cell number was $1.24 \%$, followed by lower percentages for the other concentrations, with complete death in $1000 \mu \mathrm{g} / \mathrm{mL}$. Therefore, in PBMC, the comet assay and micronucleus test were selected to be studied in the following concentrations: 10, 25, 50, and $100 \mu \mathrm{g} / \mathrm{mL}$ (Figure 1A). The results of the MTT test for HepG2 cells exposed to geraniol showed cytotoxic effects at lower concentrations, with a significant decrease in the percentage of viable cells at the concentration of $250 \mu \mathrm{g} / \mathrm{mL}$ onwards (with $2.23 \%$ viability), with only $0.45 \%$ viable cells for the concentration of $1000 \mu \mathrm{g} / \mathrm{mL}$. Concentrations of $5 \mu \mathrm{g} / \mathrm{mL}$ reduced HepG2 cell viability, presenting less than $80 \%$ values, but with a gradual reduction in viability from the concentration of $10(72.57 \%)$ to $100 \mu \mathrm{g} / \mathrm{mL}(58.23 \%)$. Then, it was only possible to choose three lower concentrations $(1.25,2.5$, and $5 \mu \mathrm{g} / \mathrm{mL}$ ) for genotoxicity assays in HepG2 cells (Figure 1B).
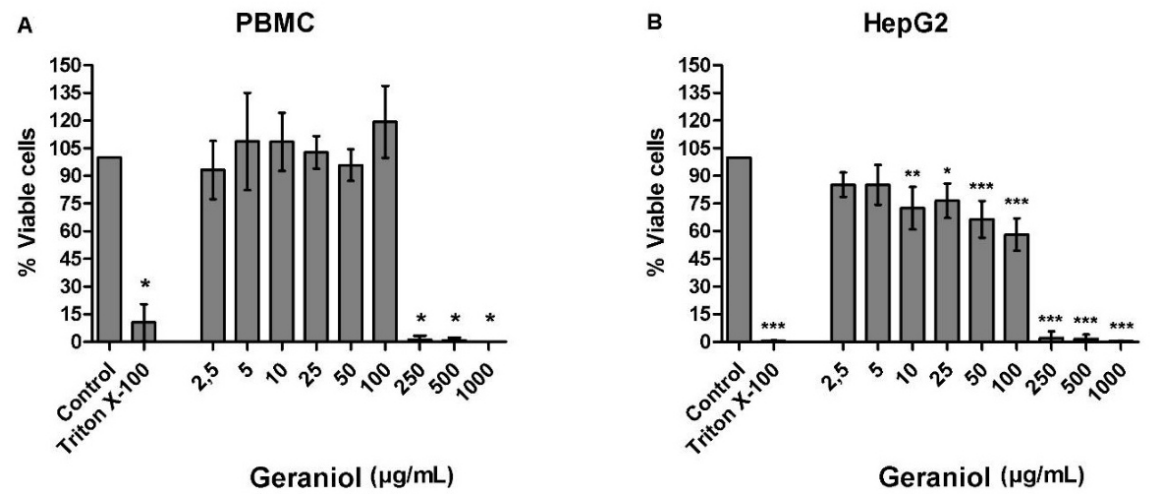

Figure 1. Percentage of viable cells in A. PBMC (human peripheral blood mononuclear cells), and $\mathbf{B}$. HepG2 cells (human hepatoma cell line HepG2), after a 24-h exposure at different geraniol concentrations $(\mu \mathrm{g} / \mathrm{mL})$ assessed by the MTT test. One-way ANOVA and Tukey multiple comparison tests showed statistically significant differences in relation to the negative control: $\mathbf{A}(* \mathrm{P}<0.001) ; \mathbf{B}(* \mathrm{P}<0.05, * * \mathrm{P}>0.01$, and $* * * \mathrm{P}<0.001)$.

The results of the geraniol assessment by comet assay showed that none of the tested concentrations caused a statistically significant increase in the number of cells damaged and their scores, both for PBMC (Table 1) and HepG2 cells (Table 2). As expected, the compound employed as a positive control (MMS for both cell types) produced a statistically significant increase in the number of damaged cells, which attested the sensitivity of the test to detect genotoxic compounds.

Table 1. DNA migration (means $\pm \mathrm{SD}$ ) in the comet assay assessing genotoxicity of geraniol ( $4 \mathrm{~h}$ of exposure) in peripheral blood mononuclear cells.

\begin{tabular}{l|c|c|c|c|c|c}
\hline \multirow{2}{*}{ Test substance } & \multirow{2}{*}{ Total $^{1}$} & \multicolumn{4}{|c}{ Comet class } & \multirow{2}{*}{ Scores } \\
\cline { 3 - 7 } & & 0 & 1 & 2 & 3 & \\
\hline Control $[$ Tween $80(8 \%)]$ & $8.67 \pm 5.16$ & $91.33 \pm 5.16$ & $6.33 \pm 4.50$ & $2.16 \pm 1.16$ & $0.16 \pm 0.40$ & $11.00 \pm 6.13$ \\
\hline Geraniol $[10 \mu \mathrm{g} / \mathrm{mL}]$ & $6.33 \pm 1.50$ & $93.67 \pm 1.50$ & $6.00 \pm 1.41$ & $0.00 \pm 0.00$ & $0.33 \pm 0.51$ & $7.00 \pm 2.09$ \\
\hline Geraniol $[25 \mu \mathrm{g} / \mathrm{mL}]$ & $3.33 \pm 2.80$ & $96.67 \pm 2.80$ & $1.66 \pm 1.36$ & $0.166 \pm 0.40$ & $1.50 \pm 1.37$ & $6.50 \pm 5.61$ \\
\hline Geraniol $[50 \mu \mathrm{g} / \mathrm{mL}]$ & $12.83 \pm 5.38$ & $86.50 \pm 5.05$ & $8.66 \pm 5.88$ & $2.33 \pm 0.81$ & $1.83 \pm 1.32$ & $18.83 \pm 6.14$ \\
\hline Geraniol $[100 \mu \mathrm{g} / \mathrm{mL}]$ & $9.33 \pm 2.06$ & $90.67 \pm 2.06$ & $3.33 \pm 2.42$ & $1.66 \pm 1.21$ & $4.33 \pm 2.33$ & $19.67 \pm 5.57$ \\
\hline MMS $[45 \mu \mathrm{M}]$ & $99.83 \pm 0.40^{\mathrm{a}}$ & $0.166 \pm 0.40$ & $0.833 \pm 1.60$ & $5.50 \pm 8.21$ & $93.50 \pm 9.64$ & $292.30 \pm 11.11^{\mathrm{a}}$ \\
\hline
\end{tabular}

$\mathrm{SD}$ = standard deviation; MMS, methyl methanesulfonate. One-way analysis of variance (ANOVA), and Tukey multiple comparison tests: statistically different from the negative control: ${ }^{\mathrm{a}}(\mathrm{P}<0.001)$. ${ }^{1}$ Total number of damaged cells (class $1+2+3$ ). 
Table 2. DNA migration (means $\pm \mathrm{SD}$ ) in the comet assay assessing genotoxicity of geraniol ( $4 \mathrm{~h}$ of exposure) in human hepatoma cell line HepG2.

\begin{tabular}{l|c|c|c|c|c|c}
\hline & Total $^{1}$ & \multicolumn{4}{|c|}{ Comet class } & \multirow{2}{*}{ Scores } \\
\cline { 3 - 7 } & & 0 & 1 & 2 & 3 & \\
\hline Cont substance & $7.33 \pm 1.15$ & $92.67 \pm 1.15$ & $7.33 \pm 1.15$ & $0.00 \pm 0.00$ & $0.00 \pm 0.00$ & $7.33 \pm 1.15$ \\
\hline Geraniol $[1.25 \mu \mathrm{g} / \mathrm{mL}]$ & $4.66 \pm 1.52$ & $95.33 \pm 1.52$ & $3.66 \pm 1.52$ & $1.00 \pm 0.00$ & $0.00 \pm 0.00$ & $5.66 \pm 1.52$ \\
\hline Geraniol $[2.5 \mu \mathrm{g} / \mathrm{mL}]$ & $8.66 \pm 5.68$ & $91.33 \pm 5.68$ & $7.33 \pm 4.93$ & $1.00 \pm 1.00$ & $0.33 \pm 0.57$ & $10.33 \pm 6.50$ \\
\hline Geraniol $[5 \mu \mathrm{g} / \mathrm{mL}]$ & $4.00 \pm 1.73$ & $96.00 \pm 1.73$ & $3.33 \pm 1.15$ & $0.66 \pm 0.57$ & $0.00 \pm 0.00$ & $4.66 \pm 2.30$ \\
\hline MMS $[45 \mu \mathrm{M}]$ & $99.33 \pm 0.57^{\mathrm{a}}$ & $0.66 \pm 0.57$ & $7.33 \pm 3.78$ & $34.00 \pm 14.00$ & $58.00 \pm 16.37$ & $249.30 \pm 18.56^{\mathrm{a}}$ \\
\hline
\end{tabular}

$\mathrm{SD}=$ standard deviation. MMS, methyl methane sulfonate. One-way analysis of variance (ANOVA), and Tukey multiple comparison tests: statistically different from the negative control: ${ }^{a}(\mathrm{P}<0.001) .{ }^{1}$ Total number of damaged cells (class $1+2+3$ ).

Tables 3 and 4 show the results of experiments designed to assess the clastogenic or aneugenic effects of the geraniol on human leukocytes and HepG2 cells, respectively. The CBMN, similarly to the results of the comet assay, showed that none of the geraniol tested concentrations produced mutagenic effects. The NPB and the nuclear buds did not show statistically significant difference in comparison with the negative control. The NDI analysis on PBMC pointed a significant decrease in cell division only on lymphocytes exposed to $100 \mu \mathrm{g} / \mathrm{mL}$ of geraniol (Table 3). In HepG2 cells, the NDI of all tested concentrations remained statistically similar to the negative control (Table 4). As expected, the compounds used as positive control to both cell types (MMS and $\mathrm{BaP}$ ) played their mutagenic effect successfully, increasing the number of binucleated cells with micronuclei, also attesting the efficiency of the test.

Table 3. Micronucleus frequency (MN), nucleoplasmic bridges (NPB), nuclear buds (NB), and nuclear division index (NDI) in peripheral blood mononuclear cells exposed at geraniol for $28 \mathrm{~h}$.

\begin{tabular}{|c|c|c|c|c|c|c|c|}
\hline \multirow[t]{2}{*}{ Test substance } & \multicolumn{2}{|l|}{ Exposure } & \multicolumn{2}{|c|}{ Binucleated cells with MN ( 2000 cells $)$} & \multirow{2}{*}{$\frac{\mathrm{NPB}}{\mathrm{N}}$} & \multirow{2}{*}{$\begin{array}{l}\mathrm{NB} \\
\mathrm{N}\end{array}$} & \multirow{2}{*}{$\begin{array}{c}\text { NDI }(1000 \text { cells }) \\
(\text { mean } \pm \text { SD })\end{array}$} \\
\hline & Concentration $(\mu \mathrm{g} / \mathrm{mL})$ & Time (h) & $\mathrm{N}$ & $\%$ & & & \\
\hline Negative control & - & 28 & 20 & 1.00 & 0 & 6 & $1.81 \pm 0.09$ \\
\hline \multicolumn{8}{|l|}{ [Tween $80(8 \%)$ ] } \\
\hline Positive control (MMS) & $150^{*}$ & 28 & $317^{\mathrm{a}}$ & $15.85^{\mathrm{b}}$ & 10 & 33 & $1.57 \pm 0.04^{\mathrm{a}}$ \\
\hline \multirow[t]{4}{*}{ Geraniol } & 10 & 28 & 25 & 1.25 & 4 & 12 & $1.71 \pm 0.07$ \\
\hline & 25 & 28 & 10 & 0.50 & 0 & 5 & $1.71 \pm 0.00$ \\
\hline & 50 & 28 & 21 & 1.05 & 2 & 1 & $1.72 \pm 0.02$ \\
\hline & 100 & 28 & 17 & 0.85 & 2 & 5 & $1.50 \pm 0.00^{\mathrm{a}}$ \\
\hline
\end{tabular}

*Concentration $=\mu \mathrm{M}$. MMS, methyl methanesulfonate. One-way analysis of variance (ANOVA), and Tukey multiple comparison tests: statistically different from the negative control: ${ }^{\mathrm{a}}(\mathrm{P}<0.05),{ }^{\mathrm{b}}(\mathrm{P}<0.001)$.

Table 4. Micronucleus frequency (MN), nucleoplasmic bridges (NPB), nuclear buds (NB), and nuclear division index (NDI) in human hepatoma cells (HepG2) exposed to geraniol for $24 \mathrm{~h}$.

\begin{tabular}{l|c|c|c|c|c|c|c}
\hline \multirow{2}{*}{ Test substance } & \multicolumn{2}{|c|}{ Exposure } & \multicolumn{2}{c|}{ Binucleated cells with MN (3000 cells) } & NPB & NB & NDI (1500 cells) \\
& Concentration $(\mu \mathrm{g} / \mathrm{mL})$ & Time $(\mathrm{h})$ & $\mathrm{N}$ & $\%$ & $\mathrm{~N}$ & $\mathrm{~N}$ & $(\mathrm{mean} \pm \mathrm{SD})$ \\
\hline Negative control & - & 24 & 45 & 1.50 & 15 & 39 & $1.38 \pm 0.02$ \\
\hline [Tween $80(8 \%)]$ & & & & & & & \\
\hline Positive control & $2 *$ & 24 & $184^{\mathrm{a}}$ & $6.13^{\mathrm{a}}$ & 41 & 61 & $1.43 \pm 0.13$ \\
\hline (Benzo(a)pyrene) & & & & & & & \\
\hline Geraniol & 1.25 & 24 & 34 & 1.13 & 4 & 22 & $1.34 \pm 0.05$ \\
\hline & 2.5 & 24 & 24 & 0.80 & 4 & 35 & $1.35 \pm 0.07$ \\
\hline & 5 & 24 & 23 & 0.76 & 10 & 28 & $1.36 \pm 0.04$ \\
\hline
\end{tabular}

*Concentraion $=\mu \mathrm{M}$. One-way analysis of variance (ANOVA), and Tukey multiple comparison tests: ${ }^{\text {a Statistically }}$ different from the negative control $(\mathrm{P}<0.001)$.

Genetics and Molecular Research 16 (3): gmr16039777 


\section{DISCUSSION}

In our continuous effort to analyze the biosafety of the use of essential oils and their constituents by humans, in this study geraniol was investigated. To perform the analysis, two distinct types of human cells: PBMC, which do not have liver biotransformation enzymes, and a transformed adherent cell line HepG2, which contain a variety of liver-metabolizing enzymes.

Our MTT test results showed that geraniol decreased the cell viability significantly to less than $70 \%$ from the $25 \mu \mathrm{g} / \mathrm{mL}$ concentration, showing that, after its metabolization by phase I and phase II hepatic enzymes, its cytotoxicity is increased from lower concentrations in comparison with PBMC (non-metabolizing cells). Several studies assign potent cytotoxic effect of monoterpenes, including geraniol, on tumor cells (Bakkali et al., 2008; Vieira et al., 2011; Crespo et al., 2013; Sobral et al., 2014; Lee et al., 2016). Considering that HepG2 is a cell line derived from the liver tumor, the noted reduction in the percentage of viable cells for the concentration of $10 \mu \mathrm{g} / \mathrm{mL}$ geraniol onwards, might, therefore, be justified, once the same cytotoxicity pattern was not obtained when used normal cells. Literature data demonstrate that geraniol specifically suppresses the tumor growth, but not affect the normal physiology of individual cells (Cho et al., 2016). The decrease in the cell proliferation and the increase of apoptosis in HepG2 cells, according to Crespo et al. (2013), pertain to the inhibitory effect on mevalonate pathways and phosphatidylcholine biosynthesis, both promoted by geraniol. The first performs an important role in the cholesterol synthesis, necessary for the rapid growth of cancer cells and their proliferation and the second is a pathway associated with apoptosis. According to Cho et al. (2016), in liver cancer, geraniol inhibits the resisting cell death; however, is still unknown how this occurs. It is believed that this monoterpene affects signaling molecules related to the acquisition of cancer hallmarks, particularly those involved in the cell cycle and apoptosis (Cho et al., 2016). Sawada et al. (2016) suggest that beyond geraniol modulates the mechanisms of cell cycle arrest and induction of apoptosis also modulates the processes involved in the inhibition of angiogenesis, cooperating with their antitumor effect in the liver.

Using the MTT test, Usta et al. (2009) also noted a decrease in the viability of HepG2 cells when exposed to $100 \mu \mathrm{M}$ geraniol. When the same concentration was used to myrcene, monoterpene analogous to geraniol, the cell viability was reduced to $26 \%$ in HepG2. Nonetheless, among the researched compounds, the more effective cytotoxic effect on HepG2 cells was assigned to linalool - another monoterpene similar to geraniol -, resulting in 50 and $100 \%$ of dead cells for the low concentrations of 0.4 and $2 \mu \mathrm{M}$ linalool, respectively (Usta et al., 2009). According to the above authors, significant decrease in viability occurred with rising linalool concentrations, which was responsible for inhibiting the mitochondrial complexes I and II of the electron transport chain, promoting a decrease in the ATP levels, energy source to the repair process, and regulation of intracellular components; in addition to providing increase in the intracellular level of reactive oxygen species (ROS); events that promoted the HepG2 cells death. DNA injury may be triggered to ROS. This idea could be applied to the cytotoxic effect of geraniol in HepG2 cells observed in our present study; however, this needs to be investigated in a further complementary analysis. However, our cytotoxicity results indicate that geraniol, as also observed by other authors to similar monoterpenes, can reduce the cell viability on human hepatoma cell line HepG2.

More recently, Sinha et al. (2014) evaluated the cytotoxic potential of six concentrations of geraniol (100-2000 $\mu \mathrm{g} / \mathrm{mL})$ on human lymphocytes, by Trypan blue dye exclusion method

Genetics and Molecular Research 16 (3): gmr16039777 
and MTT assay. In both tests, none of the tested concentrations were cytotoxic, which differ in our study when using concentrations above $100 \mu \mathrm{g} / \mathrm{mL}$ that promoted a drastic reduction in PBMC viability, with complete death using $1000 \mu \mathrm{g} / \mathrm{mL}$ geraniol. This difference can be related to the difference in the exposure time to geraniol: whereas we employed $24 \mathrm{~h}$, Sinha et al. (2014) treated the cells for $3 \mathrm{~h}$.

The association between comet assay and CBMN has been suggested for the genotoxic evaluation of chemicals, since the first detects genomic lesions as DNA singleand double-strand breaks and alkali-labile sites, whose repair process is possible; whereas the second identifies chromosomal aberration, i.e., acentric chromosomal fragments resulting from DNA breaks, or entire chromosome loss during anaphase, both without repair possibility (Van Goethem et al., 1997; Gontijo and Tice, 2003). In the present study, geraniol was not genotoxic (comet assay, after $4 \mathrm{~h}$ of exposure to geraniol), neither mutagenic (CBMN, after 28 $\mathrm{h}$ of exposure to geraniol), in both PBMC and HepG2 cells.

Previous in vivo and in vitro genotoxic assessment of geraniol on different rodent models showed contrasting results. Ishidate et al. (1984) reported that Chinese hamster fibroblast cell line (CHL) exposed to geraniol diluted in DMSO $(0.125 \mathrm{mg} / \mathrm{mL})$ significant increase polyploidy (8\%) and chromosomal aberration (4\%), in the chromosomal aberration assay. However, another endpoint investigated by the authors showed that, by the Ames test, geraniol $(0.5 \mathrm{mg} /$ plate $)$ did not induce revertant colonies, thus was not mutagenic. Lapczynski et al. (2008) confirm the absence of mutagenic effects of geraniol in bacteria but also reported the absence of cytogenetic damage in Chinese hamster ovary cells (CHO-K1) exposed to this monoterpene at 33.3, 100, and $333 \mu \mathrm{M}$, unlike what was observed by Ishidate et al. (1984).

Doppalapudi et al. (2007) observed that geraniol did not induce a significant increase in micronucleus of mice treated with 375,750 , and $1500 \mathrm{mg} / \mathrm{kg}$ and also did not induce gene mutation in Salmonella by the Ames test. On the other hand, the authors pointed as "inconclusive" the chromosomal aberration assay in Chinese hamster ovary cells $(\mathrm{CHO} / \mathrm{CA})$, because in a first trial, the tested concentrations of 78.1-156.3 $\mu \mathrm{g} / \mathrm{mL}$, in the presence of S9 metabolization fraction, showed a significant increase in the number of cells with structural aberration, but the same was not confirmed by a second trial. Despite this, in both experiments, there was a significant increase of sister-chromatid exchanges $(0.5-2.5 \%)$, which was not observed in the control groups.

Sinha et al. (2014) assessed the genotoxic potential of geraniol on human lymphocytes by the comet assay in concentrations ranging from 100 to $2000 \mu \mathrm{g} / \mathrm{mL}$ and reported that, after a 3-h exposition, it did not show genotoxic effects. The same was observed in the present study on PBMC using lower concentrations.

Although the literature data confirm HepG2 cells as an excellent cell type with metabolic capability in the detection of environmental and chemical genotoxins (ValentinSeverin et al., 2003; Knasmüller et al., 2004), our findings showed that the cytotoxic action of some monoterpenes on HepG2 cells led us to consider that HepG2 cells cannot be the most appropriate metabolizing model for genetic-toxicological studies of monoterpenes, due to its specific cytotoxic action on tumor cells, allowing to select lower concentrations of these compounds in the tests.

In conclusion, under the conditions employed in this study, our results indicate that geraniol does not present genotoxic and/or clastogenic/aneugenic effects in human cells with and without liver enzyme metabolization. On the other hand, caution is needed in the use of this monoterpene due to the cytotoxicity observed when employed concentrations above 
$100 \mu \mathrm{g} / \mathrm{mL}$. Although the geraniol is a promising compound that could be very useful in the medicine in the future, the contrasting results reported in the literature involving its cytotoxic and genotoxic potential indicate that further studies are necessary to establish safe doses of its use, better understand its mechanisms of action, and its genetic toxicity.

\section{Conflicts of interest}

The authors declare no conflict of interest.

\section{ACKNOWLEDGMENTS}

We thank Larissa Zochio for its technical support and Juliano Gabriel Froder for the MTT assay in HepG2 cells. Thaís Bernardes de Queiroz also would like to thank CAPES Coordenação de Aperfeiçoamento de Pessoal de Nível Superior - for the Scholarships. The research was supported by the FAPESP - Fundação de Amparo à Pesquisa do Estado de São Paulo (Grants 2014/26882-2), Brazil, and Research Fund from UNESP, Marília, Brazil.

\section{REFERENCES}

Bakkali F, Averbeck S, Averbeck D and Idaomar M (2008). Biological effects of essential oils - a review. Food Chem. Toxicol. 46: 446-475. https://doi.org/10.1016/j.fct.2007.09.106

Barros FMC, Zambarda EO, Heinzmann BM and Mallman CA (2009). Variabilidade sazonal e biossíntese de terpenóides presentes no óleo essencial de Lippia alba (Mill.) N. E. Brown (Verbenaceae). Quim. Nova 32: 861-867. https://doi. org $/ 10.1590 / \mathrm{S} 0100-40422009000400007$

Bhalla Y, Gupta VK and Jaitak V (2013). Anticancer activity of essential oils: a review. J. Sci. Food Agric. 93: 3643-3653. https://doi.org/10.1002/jsfa.6267

Burdock GA (2010). Fenaroli's handbook of flavor ingredients. 6th edn. CRC Press - Taylor and Francis Group, United States.

Burke YD, Stark MJ, Roach SL, Sen SE, et al. (1997). Inhibition of pancreatic cancer growth by the dietary isoprenoids farnesol and geraniol. Lipids 32: 151-156. https://doi.org/10.1007/s11745-997-0019-y

Carnesecchi S, Schneider Y, Ceraline J, Duranton B, et al. (2001). Geraniol, a component of plant essential oils, inhibits growth and polyamine biosynthesis in human colon cancer cells. J. Pharmacol. Exp. Ther. 298: 197-200.

Carnesecchi S, Langley K, Exinger F, Gosse F, et al. (2002). Geraniol, a component of plant essential oils, sensitizes human colonic cancer cells to 5-Fluorouracil treatment. J. Pharmacol. Exp. Ther. 301: 625-630. https://doi.org/10.1124/jpet.301.2.625

Carvalho KI, Bonamin F, Dos Santos RC, Périco LL, et al. (2014). Geraniol-a flavoring agent with multifunctional effects in protecting the gastric and duodenal mucosa. Naunyn Schmiedebergs Arch. Pharmacol. 387: 355-365. https://doi. org/10.1007/s00210-013-0947-z

Chen W and Viljoen AM (2010). Geraniol - A review of a commercially important fragrance material. S. Afr. J. Bot. 76: 643-651. https://doi.org/10.1016/j.sajb.2010.05.008

Cho M, So I, Chun JN and Jeon JH (2016). The antitumor effects of geraniol: Modulation of cancer hallmark pathways (Review). Int. J. Oncol. 48: 1772-1782. https://doi.org/10.3892/ijo.2016.3427

Crespo R, Montero Villegas S, Abba MC, de Bravo MG, et al. (2013). Transcriptional and posttranscriptional inhibition of HMGCR and PC biosynthesis by geraniol in 2 Hep-G2 cell proliferation linked pathways. Biochem. Cell Biol. 91 : 131-139. https://doi.org/10.1139/bcb-2012-0076

Doppalapudi RS, Riccio ES, Rausch LL, Shimon JA, et al. (2007). Evaluation of chemopreventive agents for genotoxic activity. Mutat. Res. 629: 148-160. https://doi.org/10.1016/j.mrgentox.2007.02.004

Eisenbrand G, Pool-Zobel B, Baker V, Balls M, et al. (2002). Methods of in vitro toxicology. Food Chem. Toxicol. 40: 193-236. https://doi.org/10.1016/S0278-6915(01)00118-1

Fenech M (2000). The in vitro micronucleus technique. Mutat. Res. 455: 81-95. https://doi.org/10.1016/S0027$\underline{5107(00) 00065-8}$

Gontijo AMMC and Tice R (2003). Teste do cometa para a detecção de dano no DNA e reparo em células individualizadas. In: Mutagênese Ambiental (Ribeiro LR, Salvadori DMF and Marques EK, eds.). Editora da Ulbra, Canoas.

Hartmann A and Speit G (1997). The contribution of cytotoxicity to DNA-effects in the single cell gel test (comet assay).

Genetics and Molecular Research 16 (3): gmr16039777 
Toxicol. Lett. 90: 183-188. https://doi.org/10.1016/S0378-4274(96)03847-7

Hewitt NJ and Hewitt P (2004). Phase I and II enzyme characterization of two sources of HepG2 cell lines. Xenobiotica 34: 243-256. https://doi.org/10.1080/00498250310001657568

Ishidate M, Jr., Sofuni T, Yoshikawa K, Hayashi M, et al. (1984). Primary mutagenicity screening of food additives currently used in Japan. Food Chem. Toxicol. 22: 623-636. https://doi.org/10.1016/0278-6915(84)90271-0

Klaude M, Eriksson S, Nygren J and Ahnström G (1996). The comet assay: mechanisms and technical considerations. Mutat. Res. 363: 89-96. https://doi.org/10.1016/0921-8777(95)00063-1

Knasmüller S, Mersch-Sundermann V, Kevekordes S, Darroudi F, et al. (2004). Use of human-derived liver cell lines for the detection of environmental and dietary genotoxicants; current state of knowledge. Toxicology 198: 315-328. https://doi.org/10.1016/j.tox.2004.02.008

Llana-Ruiz-Cabello M, Pichardo S, Maisanaba S, Puerto M, et al. (2015). In vitro toxicological evaluation of essential oils and their main compounds used in active food packaging: A review. Food Chem. Toxicol. 81: 9-27. https://doi. org/10.1016/j.fct.2015.03.030

Lapczynski A, Bhatia SP, Foxenberg RJ, Letizia CS, et al. (2008). Fragrance material review on geraniol. Food Chem. Toxicol. 46 (Suppl 11): S160-S170. https://doi.org/10.1016/j.fct.2008.06.048

Lee S, Park YR, Kim SH, Park EJ, et al. (2016). Geraniol suppresses prostate cancer growth through down-regulation of E2F8. Cancer Med. 5: 2899-2908. https://doi.org/10.1002/cam4.864

Madankumar A, Jayakumar S, Gokuladhas K, Rajan B, et al. (2013). Geraniol modulates tongue and hepatic phase I and phase II conjugation activities and may contribute directly to the chemopreventive activity against experimental oral carcinogenesis. Eur. J. Pharmacol. 705: 148-155. https://doi.org/10.1016/j.ejphar.2013.02.048

Maistro EL (2014). The In Vivo Rodent Micronucleus Test. In: Genotoxicity and DNA Repair: A Practical Approach (Sierra LM and Gaivão I, eds.). Humana Press, New York.

Mosmann T (1983). Rapid colorimetric assay for cellular growth and survival: application to proliferation and cytotoxicity assays. J. Immunol. Methods 65: 55-63. https://doi.org/10.1016/0022-1759(83)90303-4

OECD (2014). Test No. 487: In Vitro Mammalian Cell Micronucleus Test, OECD Publishing, Paris.

Rekha KR, Selvakumar GP, Sethupathy S, Santha K, et al. (2013). Geraniol ameliorates the motor behavior and neurotrophic factors inadequacy in MPTP-induced mice model of Parkinson's disease. J. Mol. Neurosci. 51: 851862. https://doi.org/10.1007/s12031-013-0074-9

Sawada S, Okano J, Imamoto R, Yasunaka Y, et al. (2016). Preventive Effect of Geraniol on Diethylnitrosamine-Induced Hepatocarcinogenesis in Rats. Yonago Acta Med. 59: 37-43.

Sharma Y, Khan LA and Manzoor N (2016). Anti-Candida activity of geraniol involves disruption of cell membrane integrity and function. J. Mycol. Med. 26: 244-254. https://doi.org/10.1016/j.mycmed.2016.04.004

Singh NP, McCoy MT, Tice RR and Schneider EL (1988). A simple technique for quantitation of low levels of DNA damage in individual cells. Exp. Cell Res. 175: 184-191. https://doi.org/10.1016/0014-4827(88)90265-0

Sinha S, Jothiramajayam M, Ghosh M and Mukherjee A (2014). Evaluation of toxicity of essential oils palmarosa, citronella, lemongrass and vetiver in human lymphocytes. Food Chem. Toxicol. 68: 71-77. https://doi.org/10.1016/j.fct.2014.02.036

Sobral MV, Xavier AL, Lima TC and de Sousa DP (2014). Antitumor activity of monoterpenes found in essential oils. Sci. World J. 2014: 953451. https://doi.org/10.1155/2014/953451

Solórzano-Santos F and Miranda-Novales MG (2012). Essential oils from aromatic herbs as antimicrobial agents. Curr. Opin. Biotechnol. 23: 136-141. https://doi.org/10.1016/j.copbio.2011.08.005

Tennant RW (2014). Mutagens and Carcinogens, in AccessScience. McGraw-Hill Education, Chicago. doi. org/10.1036/1097-8542.441100.

Usta J, Kreydiyyeh S, Knio K, Barnabe P, et al. (2009). Linalool decreases HepG2 viability by inhibiting mitochondrial complexes I and II, increasing reactive oxygen species and decreasing ATP and GSH levels. Chem. Biol. Interact. 180: 39-46. https://doi.org/10.1016/j.cbi.2009.02.012

Valentin-Severin I, Le Hegarat L, Lhuguenot JC, Le Bon AM, et al. (2003). Use of HepG2 cell line for direct or indirect mutagens screening: comparative investigation between comet and micronucleus assays. Mutat. Res. 536: 79-90. https://doi.org/10.1016/S1383-5718(03)00031-7

Van Goethem F, Lison D and Kirsch-Volders M (1997). Comparative evaluation of the in vitro micronucleus test and the alkaline single cell gel electrophoresis assay for the detection of DNA damaging agents: genotoxic effects of cobalt powder, tungsten carbide and cobalt-tungsten carbide. Mutat. Res. 392: 31-43. https://doi.org/10.1016/S0165-1218(97)00043-8

Vieira A, Heidor R, Cardozo MT, Scolastici C, et al. (2011). Efficacy of geraniol but not of $\beta$-ionone or their combination for the chemoprevention of rat colon carcinogenesis. Braz. J. Med. Biol. Res. 44: 538-545. https://doi.org/10.1590/ $\underline{\mathrm{S} 0100-879 \times 2011000600007}$

Woolf A (1999). Essential oil poisoning. J. Toxicol. Clin. Toxicol. 37: 721-727. https://doi.org/10.1081/CLT-100102450

Genetics and Molecular Research 16 (3): gmr16039777 